\title{
Workplace Democratic Practices and Industrial Relations Climate: A Study on Large Scale Apparel Company in Western Province, Sri Lanka
}

\author{
C. N. Vidyarathne ${ }^{1}$, K. A. S. Dhammika ${ }^{2}$ and M. V. S. Mendis ${ }^{3}$ \\ ${ }^{1}$ Ernst \& Young, Sri Lanka \\ ${ }^{2,3}$ Department of Human Resource Management, Faculty of Commerce and \\ Management Studies, University of Kelaniya, Sri Lanka \\ 11vidyarathnachamali@gmail.com, 22kasdhammika@yahoo.com \\ 3virangisonali2@gmail.com \\ iD https://orcid.org/0000-0002-3998-8066
}

\begin{abstract}
Workplace democracy is often associated with increased employee engagement and involvement, innovation and increased employee commitment. It is one of the important concepts in today's business world and through our research we have find out its impact on industrial relations climate. The research was carried out in a large scale apparel manufacturing organization of Sri Lanka, which is further known as a major player in the apparel manufacturing industry. This study empirically evaluated five workplace democratic practices (open communication, improved trust and less fear, employee empowerment, freedom of association and meaningful work) and their likely impact on the industrial relation climate in the Sri Lankan large scale apparel manufacturing organization. Non-executives of the selected organization were investigated by using a sample of 200 employees. Data collection was done by using a self-administrated structured questionnaire. The study confirmed that workplace democratic practices are significantly correlated with industrial relations climate. The findings of the study indicate that open communication, improved trust and less fear, employee empowerment, freedom of association variables were positively and significantly correlated with industrial relation climate whereas the meaningful work was negatively correlated with industrial relation climate.
\end{abstract}

Keywords: Workplace Democratic practices, Industrial Relations Climate, Apparel Industry

\section{Introduction}

Workplace democracy and industrial relations climate are two main interconnected variables which addresses the industrial peace and productivity. Workplace democracy can be defined as a variety of 
interpersonal and/or structural arrangements which link organizational decision-making to the interests and influence of employees at various levels (Petersson \& Spängs, 2005).

Workplace democracy is linked to employee participation and organizational decision making process. Further, industrial relations climate is generally used to describe the nature and quality of relationships between labor and management in the organization (Katz, Kochan \& Gobeille, 1983). According to Blyton, Dastmalchian \& Adamson (1987) industrial relations climate reflects the perceptions of organizational members about the norms, conduct, practice and atmosphere of union management relations in the workplace. More precisely, workplace democracy practices in an organization, directly effects on maintaining a healthy industrial relations climate in order to maintain minimum disputes and harmonious work relationships. In the current context, workplace democracy has become more critical since it affects to the industrial relations climate of an organization as well as for the all industries. When better workplace democracy practices are in place, the industrial relations climate becomes peaceful and positive (Jain, 1980).

However, in the apparel sector of Sri Lanka there are strikes and loss of man days take place due to industrial unrest and undemocratic work environment. Long and unpredictable working hours and safety concerns make difficult for women to balance their work- life. Further, low wages, weak collective bargaining opportunities and lack of equal pay for work of equal value can make women vulnerable to exploitation inside and outside the workplace (Kelegama \& Wijayasiri, 2004). In this backdrop, this study was aimed at examining the industrial democratic practices and their impact on industrial relation climate in the apparel industry of Sri Lanka.

\section{Literature Review}

Workplace democracy has become an important concept in the current globalized world. Workplace democracy has its own wider spectrum which discusses on worker freedom. Democracy concept has its own connection with philosophy and the thoughts (Skelley, 1989).Workplace democracy suggests that it would give workers a more creative and responsible role in making decisions, thus breeding increased capacities, competencies and more positive attitudes required for societal and political citizenship (Hatcher, 
2007). From a scholarly standpoint, contemporary research on workplace democracy is still developing. Workplace democracy has been theorized by Dahl (1985) as a moral right. Further, he describes workplace democracy as "The right to self-government through the democratic process is itself one of the most fundamental rights that a person can possess" (p.148).

Work place democracy has been subjective to the focus of researchers over the past years. As a result, some factors associated with industrial democracy have been identified. As per Pyman, Teicher \& Cooper (2010) it is claimed that voice arrangement or open communication is more likely to be associated with favorable employee perceptions of the industrial relations climate. According to Pyman et al. (2010), voice arrangements or communication happening in the organization, will directly affects the positive industrial relations climate which further creates positive employee perception towards the organization. For facilitative industrial relations, persistent, effective and transparent communication is a must as it contributes to successful change management (Sharma, Sahoo \& Sundaray, 2014). Further, research has explored the relationship between open communication and positive industrial relations climate (Ayoko, 2007).

Another dimension of workplace democracy is the improved trust and less fear. There are very limited literature available relevant to this dimension. According to Luhmann (1979), trust is considered as a coordination mechanism to reduce social complex. Trust enhanced the quality and quantity of communications, the resource availability from timely and accurate information, and cooperation among constituents as they share responsibility for the firm's performance. Further the organization could have the compliancy skill in order to respond to its environments through trust among organizational members'. After all, it depicts that there is a relationship between trust and industrial relations. Some of the previous research have explained that, employees feel fear of supervisors, presenting suggestions and feedback, fear of threats and harassments (Friedman, 1986). The literature proves that, fear at workplace will impact negatively on the industrial relations and if such is eliminated, it will affect positively on industrial relations.

Extensive research proved that employee empowerment or employee engagement which is a workplace democratic practice, has a positive 
relationship with industrial relations climate (Talukdar, 2013). Organizations have to understand that when change is on the horizon, positive employee relations can be built by analyzing the skill gaps that will always be created by change, and moving rapidly to create targeted learning opportunities to close them in time to prevent a sense of organizational helplessness so that those impacted by the proposed change have a safety net of training and skills development available to them (Moran \& Brightman, 2000). Further, Sharma et al. (2014) have explained that employee empowerment and involvement will have a significant impact on positive industrial relations climate. When analyzing holistically, it can be summaries that focus on employee empowerment can contribute to positive industrial relations.

Mclaughlin and Rasmussen (1998) have conducted a research on freedom of choice and flexibility in the retail sector. Their paper also raises questions about research in the secondary labor market. International Labor Organization further explains that the exercise of the rights to freedom of association and collective bargaining requires a conducive and enabling environment. (International Labor Organization, 2014). The main elements of a conductive environment are a legislative framework providing the necessary protections and guarantees, institutions to facilitate collective bargaining and address possible conflicts, efficient labor administrations and, very importantly, strong and effective workers' and employers' organizations. The role of governments in providing an enabling environment has paramount importance. This depicts that freedom of association has a direct impact on positive industrial relations climate

Meaningful work describes work that is worthwhile, significant, satisfying, and conducive to personal growth, self-efficacy, self-esteem, belongingness, and well-being (Ciulla, 2015).Workers try to increase the proportion of positive cues extracted from work to make their work more meaningful. The three main tactics for increasing the proportion of positive cues are cognitively emphasizing the positive qualities of work, developing competencies to be better able to produce positive outcomes and positive reactions from others, and influencing the work content' (Vuori, San \& Kira, 2012,p.231). This statement of Vuori et al (2012) indirectly shows that when meaningful work is existing in the organization, employees become positive and it will affect the industrial relations climate positively. Workplace 
democracy is not possible without 'alienated and meaningful work' (Mason, 1982, p.102). This further elaborates that alienated or isolated and meaningless work disturbs workplace democracy and in the same way as a result, it would affect the industrial relations climate negatively. Further, Hackman and Oldham (1976) define meaningful work as "the degree to which the employee experiences the job as one which is generally meaningful, valuable, and worthwhile so that it could be negative or positive" (p. 162).

\subsection{Industrial Relations Climate}

Nicolson (1979) was the first author who has identified the use of the concept of industrial relations climate. Further, Warr (1978) conducted a broad study of employee relations which highlights the importance of industrial relations climate. The term industrial relations climate is generally used to describe the nature and quality of relationship between labor and management (Katz, Kochan \& Gobeille, 1985). Industrial relations climate is the degree to which the labor-management relations are cooperative or conflicting, reflected in the extent to which relations between management and employees are seen by participants as mutually trusting, respectful, and cooperative (Hammer, Currall \& Stern, 1991). Payne and Pugh (1976) stated the usefulness of positive industrial relations climate as it improves employee motivation, satisfaction, quality of work life and overall organizational effectiveness.

Industrial relations climate has increasingly been recognized as a multidimensional concept, particularly in light of the decline in trade union density and coverage, and an associated increase in non-union workplaces, the increased use of direct voice, and the relationship between workplace democratic practices and organizational performance (Kersley, Alpin, Forth, Bryson, Bewley, Dix and Oxenbridge, 2006). Further, according to Kersley Oxenbridge et al. (2006) industrial relations climate affects workplace outcomes. Schneider and Reichers (1983) stated that industrial relations climate is a function of the interactions between 'organizational members', individuals and groups within an organization.

\section{Conceptual Framework}

Conceptual framework of the study depicts a theoretical framework which discusses the interrelationship of the dependent variable and independent 
variables. The conceptual framework of the study can be mentioned as below and there are five independent variables such as open communication (Ayoko, 2007; Pyman, Teicher \& Cooper, 2010; Sharma, Sahoo \& Sundaray, 2014), improved trust and less fear (Luhmann, 1979; Friedman, 1986), employee empowerment, freedom of association (Talukdar, 2013; Sharma et al. 2014) and meaningful work (Mclaughlin and Rasmussen, 1998; Ciulla, 2015) which are categorized under workplace democratic practices Further the dependent variable is known as industrial relations climate (Warr, 1978; Hammer, Currall \& Stern, 1991; Kersley, Alpin, Forth, Bryson, Bewley, Dix and Oxenbridge, 2006).

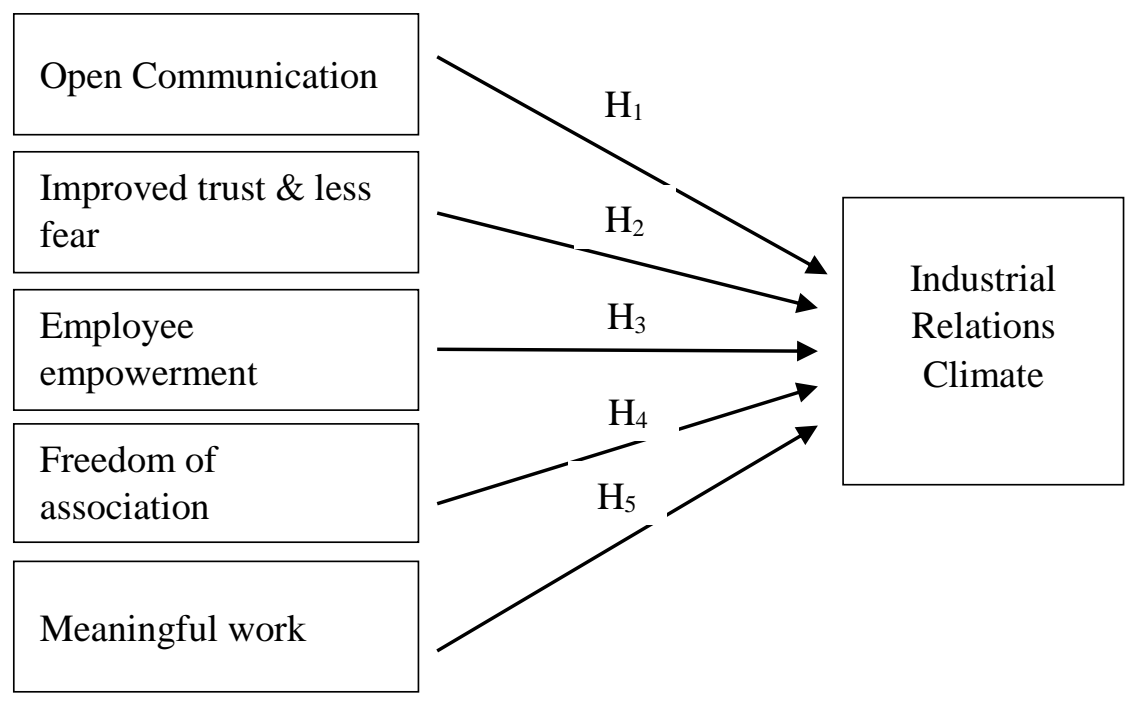

\section{Figure 1: Conceptual Framework}

Source: Authors Constructed (2017)

\section{Hypotheses of the Study}

Based on the conceptual framework the researcher developed following hypotheses.

$\mathbf{H}_{\mathbf{1}}$ : There is a significant positive relationship between open communication and industrial relations climate 
$\mathbf{H}_{2}$ : There is a significant positive relationship between improved trust and less fear and industrial relations climate

$\mathbf{H}_{3}$ : There is a significant positive relationship between employee empowerment and industrial relations climate

$\mathbf{H}_{4}$ : There is a significant positive relationship between freedom of association and industrial relations climate

$\mathbf{H}_{5}$ : There is a significant positive relationship between meaningful work and industrial relations climate

\section{Methodology}

The study relied on survey method as the researchers assumed it to be the most appropriate method according to the nature of the study. The population of the study was 666 non executives in which 200 was selected as the sample. The simple random sampling was used as the sampling technique. Data were collected using a self-administrated structured questionnaire. The questionnaire consisted of 36 questions and the section one of the questionnaire designed to obtain demographic characteristics, including marital status, age and the length of work experience etc. In the second section there are 25 questions regarding workplace democratic practices. In the independent variable section of the questionnaire, 5 questions were used to measure the open communication variable, 6 questions were used to measure improved trust and less fear variable, another 5 questions were used to measure employee empowerment variable while 4 questions were used to measure freedom of association variable and 5 more questions were used to measure meaningful work variable. Finally the third section consists of 7 questions regarding industrial relations climate.

Some of the questions were close ended to obtain nominal and ordinal data, whiles others scored on a 5-point Likert scale. Point 1 for strongly agree, 2 for agree, 3 for neutral, 4 for disagree and 5 for strongly disagree have been provided to analyze data. 


\subsection{Reliability and Validity Analysis}

The reliability of a measure indicates the extent to which it is without bias (error free) and hence ensures consistent measurement across time and across the various items in the instrument. In other words, the reliability of a measure is an indication of the stability and consistency with which the instrument measures the concept and helps to assess the "goodness" of a measure (Sekaran, 2006). This can be tested statistically by using Cronbach's alpha. The reliability statistics indicated 0.796 for the Cronbach's Alpha value for 32 numbers of items which is suggesting that the items have relatively high internal consistency.

Validity is often defined as the extent to which an instrument measures what it supposed to measure. According to Sekaran (2006), validity can be explained as the extent to which can be reasonably certain that the selected questions are measuring the exact concept set out by the researcher. KMO measure of sample adequacy was 0.752 and the significance value was 0.000 . As the standard KMO measure of sample adequacy value is greater than 0.5 , and the significance value is less than 0.05 , it can be concluded that the total validity test is valid.

\section{Results and the Discussion}

\subsection{Sample Composition}

Demographic factors of the respondents were analyzed in order to understand the nature of the sample. Accordingly, it was found that 33\% of respondents were in the age range of 25 years or less while $49 \%$ of them belong to 26-36 years range. Further, 18\% was from 36 years and above.

In case of marital status, it was recorded that $53.5 \%$ were married while $46.5 \%$ were single. Other than that it was found that $55.5 \%$ of respondents had a service period of less than 5 years and $33.5 \%$ had a service period between 5-10 years. Only 11\% of them had a service period of more than 10 years.

The results indicate that majority of the respondents were middle aged and more employees are married. Further majority of respondents have less than 5 years' work experience which indicate that employees not retained in the same workplace for a long period of time. 


\subsection{Descriptive Statistics}

\section{Table 1: Descriptive Statistics}

\begin{tabular}{|l|c|c|c|c|c|}
\hline & N & Min & Max & Mean & SD \\
\hline Open communication & 200 & 1 & 5 & 11.69 & 3.618 \\
\hline Improved trust and less fear & 200 & 1 & 5 & 16.95 & 3.271 \\
\hline Employee empowerment & 200 & 2 & 5 & 13.03 & 4.283 \\
\hline Freedom of association & 200 & 1 & 4 & 10.41 & 2.816 \\
\hline Meaningful work & 200 & 1 & 5 & 16.90 & 4.046 \\
\hline Workplace Democracy & 200 & 2 & 5 & 68.99 & 10.305 \\
\hline Industrial relations climate & 200 & 1 & 4 & 17.97 & 5.361 \\
\hline Valid N (list wise) & 200 & & & & \\
\hline
\end{tabular}

According to Table 1, the mean value for open communication was 3.46 with a standard deviation of 1.203. It can infer that the open communication happens to a significant degree in the selected sample. The same scenario can be observed with employee empowerment and freedom of association. The mean value recorded for employee empowerment was 4.01 with a standard deviation of 1.025 while the mean and standard deviation of freedom of association also recorded high value. The other variables namely, meaningful work, workplace democracy and industrial relation climate recorded a higher mean values too.

\subsection{Correlation Analysis}

Hypotheses were tested using Pearson's product moment correlation analysis and the results were presented in the Table 2. The correlations between the variables of the study namely, open communication, improved trust and less fear, employee empowerment, freedom of association and meaningful work was tested. 
Table 2: Correlations

\begin{tabular}{|l|c|c|}
\hline & $\begin{array}{c}\text { Positive industrial } \\
\text { relations climate }\end{array}$ & Sig. (2-tailed) \\
\hline Open communication & $.447^{* *}$ & .000 \\
\hline Improved trust and less fear & $.383^{* *}$ & .000 \\
\hline Employee empowerment & $.491^{* *}$ & .000 \\
\hline Freedom of association & $.515^{* *}$ & .000 \\
\hline Meaningful work & $-.324^{* *}$ & .000 \\
\hline
\end{tabular}

**. Correlation is significant at the 0.01 level (1-tailed).

The analysis of the results indicate a moderate positive correlation between freedom of association and positive industrial relations climate $(r=0.515)$ and is significant at 0.01 which means that the positive correlation observed between freedom of association and positive industrial relations climate is statistically significant. Further there is a positive relationship between employee empowerment and positive industrial relations climate $(r=0.491)$ and is significant at 0.01.The positive relationship between open communication and positive industrial relations climate $(\mathrm{r}=0.447)$ at 0.01 shows that positive industrial relations climate is correlates to the open communication. The results of improved trust and less fear reveal its significant positive correlation with positive industrial relations climate $(\mathrm{r}=$ 0.383 ) at $\mathrm{p}=0.01$. However meaningful work has a negative correlation with positive industrial relations climate $(r=-0.324)$ where $p=0.01$.

\subsection{Regression Analysis}

As a further analysis of data, regression analysis was used for identification of the possible impact of independent variables (workplace democratic practices) on dependent variable (positive industrial climate). The following tables depict the results of the regression analysis. 
Table 3: ANOVA

\begin{tabular}{|l|l|c|l|l|l|l|}
\hline \multicolumn{2}{|c|}{ Model } & $\begin{array}{c}\text { Sum of } \\
\text { Squares }\end{array}$ & df & $\begin{array}{c}\text { Mean } \\
\text { Square }\end{array}$ & F & Sig. \\
\hline \multirow{3}{*}{1} & Regression & 2305.813 & 5 & 461.163 & 26.205 & $.000^{\text {b }}$ \\
\cline { 2 - 8 } & Residual & 3414.007 & 194 & 17.598 & & \\
\cline { 2 - 8 } & Total & 5719.820 & 199 & & & \\
\hline
\end{tabular}

a. Dependent Variable: Positive industrial relations climate

b. Predictors: (Constant), Meaningful work, improved trust and less fear, Freedom of association, Employee empowerment, Open communication

\section{Table 4: Coefficients}

\begin{tabular}{|c|c|c|c|c|c|c|}
\hline & \multirow{2}{*}{ Model } & \multicolumn{2}{|c|}{$\begin{array}{l}\text { Unstandardized } \\
\text { Coefficients }\end{array}$} & \multirow{2}{*}{$\begin{array}{c}\text { St. Coeff. } \\
\text { Beta }\end{array}$} & \multirow{2}{*}{$\mathrm{t}$} & \multirow{2}{*}{ Sig. } \\
\hline & & B & $\begin{array}{l}\text { Std. } \\
\text { Error }\end{array}$ & & & \\
\hline \multirow{6}{*}{1} & (Constant) & 7.081 & 2.404 & & 2.946 & .004 \\
\hline & $\begin{array}{l}\text { Open } \\
\text { communication }\end{array}$ & .027 & .116 & .018 & .236 & .813 \\
\hline & $\begin{array}{l}\text { Improved trust } \\
\text { and less fear }\end{array}$ & .389 & .102 & .237 & 3.792 & .000 \\
\hline & $\begin{array}{l}\text { Employee } \\
\text { empowerment }\end{array}$ & .259 & .093 & .207 & 2.785 & .006 \\
\hline & $\begin{array}{l}\text { Freedom of } \\
\text { association }\end{array}$ & .501 & .135 & .263 & 3.712 & .000 \\
\hline & $\begin{array}{l}\text { Meaningful } \\
\text { work }\end{array}$ & -.273 & .085 & -.206 & -3.223 & .001 \\
\hline
\end{tabular}

a. Dependent Variable: Positive Industrial Relations Climate 
Table 5: Model Summary

\begin{tabular}{|c|c|c|c|c|c|}
\hline Model & $\mathrm{R}$ & $\begin{array}{c}\mathrm{R} \\
\text { Square }\end{array}$ & $\begin{array}{c}\text { Adjusted } \\
\mathrm{R} \\
\text { Square }\end{array}$ & $\begin{array}{c}\text { Std. Error of } \\
\text { the Estimate }\end{array}$ & $\begin{array}{c}\text { Durbin- } \\
\text { Watson }\end{array}$ \\
\hline 1 & $.635^{\mathrm{a}}$ & .403 & .388 & 4.195 & 1.899 \\
\hline
\end{tabular}

a. Predictors: (Constant), Meaningful work, improved trust and less fear, Freedom of association, Employee empowerment, Open communication

b. Dependent Variable: Positive industrial relations climate

According to the results of the regression analysis, it can reasonably claimed that the independent variables of the study namely, improved trust and less fear, employee empowerment, freedom of association, meaningful work and open communication can be used to predict the level of positive industrial climate. The regression model tested recorded $f$ value of 26.205 at $\mathrm{P}=.000$ level. This is clear indication that the model can be held valid.

The regression coefficient values shown by the Table 4 indicate that the, improved trust and less fear, employee empowerment, freedom of association and meaningful work can be considered as significant determinants of the positive industrial climate in the sample organizations. However, open communication does not seem as a significant predictor of the positive industrial climate. This can be further verifiable with the model summary statistics depicted by the Table 5 . Accordingly it can infer that nearly $40 \%$ of the variance in the positive industrial climate is explained by the significant independent variables of the study.

\section{Conclusion}

The objective of this study is to identify the relationship between workplace democracy practices and industrial relations climate in the apparel sector of Sri Lanka. The workplace democratic practices (independent variables) considered in the study are open communication, improved trust and less fear, employee empowerment, freedom of association and meaningful work which are extracted from literature. The dependent variable considered in the study was industrial relations climate. According to the statistical output, it was 
found that among the workplace democratic practices considered for this study namely, open communication, improved trust and less fear, employee empowerment and freedom of association have a positive relationship with industrial relations climate. Therefore organizations must contribute a high weightage in establishing such practices, since it ensure a positive relationship between workplace democracy and industrial relations climate.

Meaningful work, independent variable has a negative relationship with the industrial relations climate. It explains that the available work at organizations in the apparel sector is more into monotonous work areas which employees are not getting much satisfied, so that the employees feel dissatisfaction and frustration. Due to this reason it affects the industrial relations climate in a negative way.

\section{Recommendations}

As open communication has a positive impact on the industrial relations climate, it is important to improve the same in order to assure positive industrial relations. In order to improve open communication in organizations in the apparel sector, the company should ensure that the top management and the middle management are committed to open communication and be visible and available to the employees at every level. Make the communication process transparent. Hold open-ended meetings that give each team member the opportunity to share concerns, accomplishments and ideas. Setting up clear expectations for all work tasks and what you expect employee behavior to be is very important. Further, avoid springing surprises on employees on work related matters is also important. Establish a grievance system through which employees can make complaints in a protected manner. Give complaints serious consideration when warranted and always let employees know that they have been heard. Take action on complaints and communicate those actions to all involved parties.

There is a positive relationship between improved trust and less fear with positive industrial relations climate. Improved trust and less fear makes employees comfortable at work and it will support them to complete their work smoothly.

Employee empowerment has a positive relationship with positive industrial relations climate. Allowing employees a certain degree of autonomy and 
responsibility for decision-making regarding their specific organizational tasks will create a positive and peaceful industrial relations climate. The study would recommend implementing the concept of employee empowerment among the organizations in the apparel sector.

Freedom of association impacts positively on the positive industrial relations climate of the apparel sector. Mainly freedom of association is the right to join or associate a group on person's / employee's own choice in order to take collective actions to pursue the interests of members. In that case, when providing such freedom, employees feel some sort of a satisfaction and motivation in their work life and that would affect positively on the industrial relations climate of the organization. As the apparel organizations don't have unions for each individual organization (for the whole apparel sector there is one union), they do have other ways of association such as Joint Consultative Committee (JCC), Quality Circles etc. Freedom of association is important, since it would be a mode for employee voice.

Meaningful work is another independent variable which has a negative impact / relationship with positive industrial relations climate. As nonexecutive level employees are performing continuously the same job duties and responsibilities, they would not feel as it is important or much meaningful tasks. Hence, frustration and dissatisfaction will take place. Then it would affect negatively on the industrial relations climate.

\section{Directions for Future Research}

Democracy in the workplace provides a culture of balance, immersion, unity and community that is healthy in mentally and physically and as overall a positive industrial relations climate. This study has focused on few independent variables under workplace democratic practices. Further, in future research, the researchers can focus on more workplace democratic practices such as decentralization, transparency, fairness, union role on workplace democracy, voting for making decisions in the organization context and its impact on industrial relations climate.

Further, it is an important area of research, since the countries in the world are more concerned on liberty, democracy and positive industrial relations climate. This study is based on the apparel sector and future researchers can focus on different sectors such as public sector, information technology 
industry, manufacturing industry, plantation sector, construction and banking.

\section{References}

Andriessen, J. H. E. (1998). Industrial democratization and industrial relations. In P. J. D. Drenth, H. Thierry, \& C. J. Wolff (Eds.), Handbook of work and organizational psychology (2nd ed., Vol. 4, pp. 401-428). East Sussex, UK: Psychology Press.

Appelbaum, S., Karasek, R., Lapointe, F., \&Quelch, K. (2015). Employee empowerment: Factors affecting the consequent success or failure (Part II). Industrial and Commercial Training, 47(1), 23 - 30.

Ayoko, O. B. (2007). Communication openness, conflict events and reactions to conflict in culturally diverse workgroups. Cross Cultural Management: An International Journal, 14(2), $105-124$.

Blyton, P., Dastmalchian, A., \& Adamson, R. (1987). Developing the concept of industrial relations climate. Journal of industrial relations, 29(2), 207-216.

Bryman, A. (2004). Social research method (2nd Ed.). Oxford: Oxford University Press.

Cohen-Rosenthal, E. (1981). An overview of alternative approaches to worker participation. In A. Nickelhoff (Ed.), Extending workplace democracy: An overview of participatory decision making plans for unionists. Michigan: Institute of Labor and Industrial Relations.

Collom E. (2003). Two classes and one vision? Managers' and workers' attitudes toward workplace democracy. Work and Occupations, 30(1), 62-96.

Dahl, R. A. (1970). After the revolution: Authority in a good society. New Haven: Yale University Press.

Dahl, R. A. (1985). A preface to economic democracy. Berkeley: University of California Press.

Dahl, R. A. (2001). A right to workplace democracy? Response to Robert Mayer. The Review of Politics, 63(2), 249-253.

Dastmalchian, A., Blyton, P., \& Adamson, R. (2014). The Climate of Workplace Relations (Routledge Revivals). Routledge.

Dickson, J. W. (1983) Participation as an interaction, communication and influence process. Personnel Review, 12(1), 17 - 22. 
Friedman, S. D. (1986). Succession systems in large corporations: Characteristics and correlates of performance. Human Resource Management, 25(2), 191213.

Ghosh, D., \& Vogt, A. (2012). Outliers: An evaluation of methodologies. Section on Survey Research Methods - JSM.

Hackman, J. R., \& Oldham, G. R. (1976). Motivation through the design of work: Test of a theory. Organizational behavior and human performance, 16(2), 250-279.

Hammer, T., Currall, S., \& Stern, R. (1991). Worker Representation on Boards of Directors: A Study of Competing Roles. Industrial and Labor Relations Review, 44(4), 661-680. Doi: 10.2307/2524455

Hatcher, T. (2006). Democratizing the workplace through professionalization of human resource development. International journal of Training and Development, 10(1), 67-82.

Hatcher, T. (2007). Workplace democracy: A review of literature and implications for human resource development. North Carolina State University. Retrieved from http://files.eric.ed.gov/fulltext/ED504672.pdf

Haque, M. S. (2000). Threats to public workplace democracy. Peace Review, 12(2), 237-241.

International Labor Organization. (2014). Wages and working hours in the textiles, clothing, leather and footwear industries.

Jain, H. C. (1980). Worker participation and industrial relations: A conceptual framework. InH. Jain (Ed.), Worker participation: Success and problems (pp. 3-20). New York: Praeger Publishers.

Jayasinghe, A. (2010, July 3). Stop labor rights violations in the apparel sector of Sri Lanka and comply with ILO standards to protect US GSP. Retrieved from http://www.lankanewspapers.com.

Katz, H. C., Kochan, T. A., \& Gobeille, K. R. (1983). Industrial relations performance, economic performance, and QWL programs: An interplant analysis. ILR Review, 37(1), 3-17.

Katz, H. C., Kochan, T. A., \& Weber, M. R. (1985). Assessing the effects of industrial relations systems and efforts to improve the quality of working life on organizational effectiveness. Academy of Management Journal, 28(3), 509-526. 
Kelegama, S., \& Wijayasiri, J. (2004). Overview of the garment industry in Sri Lanka. Ready-made garment industry in Sri Lanka: Facing the global challenge, 13-45.

Kersley, B., Alpin, C., Forth, J., Bryson, A., Bewley, H., Dix, G., \& Oxenbridge, S. (2013). Inside the workplace: findings from the 2004 Workplace Employment Relations Survey. Routledge.

Luhmann, N. (1979). Trust and Power. Chichester, England: John Wiley.

Mason, R. M. (1982). Participatory and workplace democracy: A theoretical development in critique of liberalism. Carbondale, Ill: Southern Illinois University Press.

McLaughlin, C., \& Rasmussen, E. (1998). "Freedom of choice" and "flexibility" in the retail sector? International Journal of Manpower, 19(4), 281-295.

Moran, J. W., \& Brightman, B. K. (2000). Leading organizational change. Journal of Workplace Learning, 12(2), 66-74

Nicholson, N. (1979). Industrial relations climate: A case study approach. Personnel Review, 8, 20-25.

Pausch, M. (2013). Workplace democracy: From a democratic ideal to a managerial tool and back. The Innovation Journal: The Public Sector Innovation Journal, 19(1), 1-19.

Payne, R., \& Pugh, D. S. (1976). Organizational structure and climate. In M. D. Dunnette (ed.), Handbook of industrial and organizational psychology. Chicago: Rand McNally.

Petersson, M., \& Spängs, A. (2006). Semco \& Freys: A multiple-case study of workplace democracy.

Pyman, A., Holland, P., Teicher, J., \& Cooper, B. K. (2010). Industrial relations climate, employee voice and managerial attitudes to unions: An Australian study. British Journal of Industrial Relations, 48(2), 460-480.

Schneider, B., \& Reichers, A. (1983). On the etiology of climates. Personnel Psychology.

Sekaran, U. (2006). Research methods for business: A skill building approach. New York: John Wiley \& Sons.

Senarath, S. (2012, May 20). End of the road for the apparel industry? Retrieved from http://www.sundaytimes.lk/120520/BusinessTimes/bt29.html 
Sharma, R., Sahoo, C. K., Das, S., \& Sundaray, B. K. (2014). Mediating Role of Trade unions in between Industrial Relations and Successful Change: Validation of the Model through Structural Equation Modeling.

Skelley, B. D. (1989). Workplace democracy and OD: Philosophical and practical connections. Public Administration Quarterly, 176-195.

Sri Lanka Apparel Exporters Association. (2016). Export of apparel trade data for the month of December 2015 to all countries. Retrieved from http://www.srilanka-apparel.com/export-performance.

Talukdar, A. (2013). Employee engagement \& industrial relations climate in a large public sector organization. Indian Journal of Industrial Relations, 49 (2).

Vliet, M. (2012). An alternative organizational model: Workplace Democracy. Tilburg University.

Vuori, T. (2012). Meaningfulness-making at work. Hanken School of Economics.

Vuori, T., San, E., \& Kira, M. (2012). Meaningfulness-making at work. Qualitative Research in Organizations and Management: An International Journal, 7 (2), 231-248.

Warr, P. (1978). A study of psychological well-being. British Journal of Psychology, 69(1), 111-121. 